\title{
Range extension to Santo Domingo de los Tsáchilas province and revised distribution of Platyrrhinus chocoensis (Phyllostomidae: Chiroptera) in western Ecuador
}

\author{
Wilmer E. Pozo-Riveraa, ${ }^{1,6}$ Karolina Yazán-Ayala ${ }^{1,7}$; Ramiro Alvear-Barrezueta ${ }^{2}$; \\ Christian R. Loaiza-S. ${ }^{3}$; Vicente Berovides-Álvarez ${ }^{4}$ \& Carlos A. Mancina ${ }^{5}$
}

\footnotetext{
1 Universidad de las Fuerzas Armadas (ESPE), Departamento de Ciencias de la Vida y de la Agricultura, Laboratorio de Zoología, Museo de Investigaciones Zoológicas del IASA (MIZI). Sangolquí, Pichincha, Ecuador.

2 Ejército Ecuatoriano, Comando de Educación y Doctrina. Quito, Pichincha, Ecuador. ORCID: 0000-0003-2476-0998. E-mail: raalvearb@ejercito.mil.ec

${ }^{3}$ Universidad Nacional Mayor de San Marcos (USMSM), Museo de Historia Natural, Departamento de Mastozoología. Lima, Peru. ORCID: 0000-0001-6581-3713. E-mail: christian.loaiza@unmsm.edu.pe

${ }^{4}$ Universidad de La Habana (UH), Facultad de Biología. La Habana, Cuba. ORCID: 0000-0003-0232-6154. E-mail: vbero@fbio.uh.cu

${ }^{5}$ Ministerio de Ciencia, Tecnología y Medio Ambiente (CITMA), Instituto de Ecología y Sistemática (IES). La Habana, Cuba. ORCID: 0000-0003-3976-8458. E-mail: mancina@ecologia.cu

${ }^{6}$ ORCID:0000-0003-3848-543X. E-mail: wepozo@espe.edu.ec

7 ORCID: 0000-0003-0930-2657. E-mail: jkyazna@espe.edu.ec
}

\begin{abstract}
We report the first record of the Choco broad-nosed bat (Plathyrrhinus chocoensis Alberico \& Velazco, 1991) in Santo Domingo de los Tsáchilas province in northwestern Ecuador. This voucher specimen represents the southernmost record of the species and expands its distribution ca. $120 \mathrm{~km}$ south. The animal was caught at a farm, specifically in a live fence consisting of several tree species. Preservation of bat species occurring in agricultural landscapes requires local policies and environmental education.
\end{abstract}

Key-Words. Mammalia; Bats; Biogeography; New record; Ecuador.

\section{INTRODUCTION}

Located in the northwestern Pacific coast of South America, the Tumbes-Chocó-Magdalena bioregion is one of 25 world hotspots due to its high biodiversity (Mittermeier et al., 1999; Myers et al., 2000). This bioregion includes the ChocóDarien moist forests (Chocó) located on the Pacific coast of northwestern Ecuador (Myers et al., 2000). Ecuador, despite its small area, displays high mammalian diversity, with 424 species (Tirira, 2016). The order Chiroptera is the most numerous (Tirira, 2007; Albuja, 2011), with 171 species (Tirira, 2016) found in all zoogeographical zones in Ecuador (Albuja, et al., 2012). More specifically, the northwestern forests house at least 85 species (Tirira, 2008; Burneo \& Tirira, 2014), of which at least 20 have been recorded in agricultural landscapes (Pozo-Rivera \& Eras, 2012; Pozo-Rivera, 2013; Pozo-Rivera et al. 2015).

Ecuador Choco extends from the province of Esmeraldas to the Pasado cape in the province of Manabí (Boada, 2006). On the eastern side, it includes the lowlands of Carchi, Imbabura, Pichincha
(Botero-Chica, 2010), and Santo Domingo de los Tsáchilas to reach the Troncal locality in the province of Guayas. Ecuadorian Choco contains 9,000 species of vascular plants, 120 amphibians, 100 reptilians, 600 avians (Botero-Chica, 2010), and 167 mammals (Tirira, 2008; Jarrín-V \& Kunz, 2011; Moratelli \& Wilson, 2011). It is estimated that only $12.5 \%$ of pre-European contact, western Ecuadorian forests are conserved (Sierra et al., 2002; Boada, 2006). Causes of forest loss include expansion of agriculture, logging, population growth (Huttel, 1999), mining (Paredes, 2010), and tourism (Cueva-Arroyo et al., 2013). Although several private and state protected areas (MAE, 2015) have been established in the zone, monocultural agrosystems (Huttel, 1999) threaten the local ecology (Zuppinger-Dingley et al., 2015).

The broad-nosed bats of the genus Platyrrhinus (subfamily Stenodermatinae, family Phyllostomidae) live in tropical lowland and montane forests up to 2,550 $\mathrm{m}$ asl (Velazco \& Gardner, 2009), from Mexico to northern Argentina (Gardner, 2007). Most species are essentially frugivorous but occasionally feed on insects, nectar, 
and pollen (Albuja, 1999) by gleaning in narrow forest areas (Kalko et al., 2008). The genus Platyrrhinus is morphologically distinguished by a fringe of hair on the edge of uropatagium, molars 3/3, and two accessory cusps on M2 (Tello \& Velazco, 2003; Lim, 1993). Platyrrhinus currently contains 21 species (Simmons, 2005; Velazco \& Gardner, 2009; Velazco et al., 2010; Velazco \& Lim, 2014), of which 13 inhabit Ecuador (Albuja, 2011). Among these, P. chocoensis, P. dorsalis, P. helleri, P. lineatus, P. nitelinea, and $P$. matapalensis have been recorded in western Ecuador (Albuja, 2011).

The Choco broad-nosed bat Platyrrhinus chocoensis (Alberico \& Velazco, 1991) occurs in the lowlands of the Colombian and Ecuadorian Choco region, at elevations between 35 and 1,000 m. In Ecuador, the species is known from 29 localities (Appendix 1), with its southernmost record in Sade, Esmeraldas Province $\left(00^{\circ} 31^{\prime} 04.0^{\prime \prime} \mathrm{N}\right.$, 79²0'28.9"W) (Gardner, 2007; Ramirez-Chaves \& SuárezCastro, 2015; Loaiza-S, unpublished data). The species is classified as Vulnerable A2c, because the population decline is probably closer to over $30 \%$ and habitat loss (Ramirez-Chaves \& Suárez-Castro, 2015), but in Ecuador it is considered an endangered species (Burneo et al., 2015). Morphologically, Platyrrhinus chocoensis possesses buff facial stripes (no shine) (Albuja, 1999), a buff and undulated dorsal stripe, bicolored ventral fur (Gardner, 2007), genal vibrissae lacking a basal protuberance directly over the cheeks [a character evident only in specimens preserved in alcohol (Velazco, 2005)], one vibrissae on each side of the upper lip away from the baseline to seven vibrissae surrounding the noseleaf, one interramal vibrissae (Velazco, 2005), an inverted U-shaped posterior margin of the uropatagium, and the absence of a stylar cuspule on the lingual face of the M2 metacone (Gardner, 2007; Velazco \& Gardner, 2009).

This communication reports on the first record of Platyrrhinus chocoensis for the province of Santo Domingo de los Tsáchilas, northwestern Ecuador and proposes a new geographical distribution for the species.

\section{MATERIAL AND METHODS}

We collected bats using mist nets in an agricultural landscape in western Ecuador from September, 2012 to March, 2015. Most were identified in situ, but those that were difficult to identify were sacrificed following guidelines of the American Society of Mammalogists for the use of wild mammals in research (Sikes et al., 2011) and the specifications outlined in the Authorization of Scientific Research № 10-2013-IC-FAU-DPAP-MA granted by the Ministry of Environment of Ecuador. Voucher specimens were deposited at the Museo de Investigaciones Zoológicas del IASA, Universidad de las Fuerzas Armadas (MIZI). We identified specimens at the genus level following Jones \& Carter (1976), Albuja (1999) and Tirira (2007), and used Gardner (2007) and Velazco \& Gardner (2009) for species identification.

For comparative purposes, we also examined 31 specimens of $P$. chocoensis deposited in the Museo Ecuatoriano de Ciencias Naturales (MECN), Museo de Zoología de la Pontificia Universidad Católica de Quito (QCAZ), Instituto de Ciencias Biológicas de la Escuela Politécnica Nacional (MEPN), Museum of Texas Tech University (TTU), and Museo de Investigaciones Zoológicas (MIZI) (Appendix 1). Additionally, we measured 17 cranial variables following Velazco \& Gardner (2009). We calculated descriptive statistics of cranial and postcranial measurements using InfoEstat ${ }^{\circledR}$ (Balzarini et al., 2013). We modeled the species habitat and potential distribution using Maximum Entropy Modeling (Maxent) (Phillips et al., 2006), and we calculated home range based on historical records of the species in Ecuador using Minimum Convex Polygon (MCP). Environmental variables were downloaded from www.worldclim.org (Hijmans et al., 2005) in format ESRI grind ca $1 \mathrm{~km}$. To increase modeling accuracy, we performed 10 replicates, 500 interactions, and 10,000 background points.

\section{RESULTS}

On February 8, 2012, RAB and WEPR collected-in a life fence at San Antonio Farm (Ecuador) a bat specimen initially identified as Vampyrodes caracciolli based on the presence of two central, markedly convergent incisors (Pozo-Rivera, 2013). The specimen was deposited under museum number MIZI 2012397. However, during a recent curation of the mammal collection in MIZI, WEPR and KYA found errors with the identification of the voucher and reassigned it to Platyrrhinus chocoensis (Fig. 1) based on Gardner (2007) and Velazco \& Gardner (2009).

The specimen of Platyrrhinus chocoensis was collected at the San Antonio Farm, located close to the boundary of the Los Rios and Santo Domingo de los Tsáchilas provinces $\left(00^{\circ} 31^{\prime} 32.0^{\prime \prime} \mathrm{S}, 79^{\circ} 19^{\prime} 21.3^{\prime \prime} \mathrm{W}\right)$, at an elevation of $327 \mathrm{~m}$ asl (Fig. 2), and was identified as an adult male. The animal was caught by mist nets placed over a biodiverse life fence composed of several plant species (Erythrina smithiana, Citrus spp., Coffea arabiga, Jatropa curcas, and others). Other bat species collected at the same farm were Artibeus aequatorialis, Carollia brevicauda, C. perspicillata, Chiroderma villosum, Glossophaga soricina, Myotis riparius, Sturnira lilium, and Vampyriscus nymphaea (Pozo-Rivera, 2017). This record extends the range distribution of Platyrrhinus chocoensis ca. $120 \mathrm{~km}$ south, away from its currently recognized distribution area (Gardner, 2007; Ramirez-Chaves \& Suárez-Castro, 2015).

The predictive model using Maxent, based on $31 \mathrm{spec}-$ imens with accurate collection sites, is shown in Fig. 2; the area under curve (AUC) value of receiver operating characteristic curve (ROC) was 0.987. Based on these reports, the home range of the species, calculated by minimum convex polygon, reaches $14,904.7 \mathrm{~km}^{2}$ (Fig. 2). Environmental variables which most influenced the distribution modeling were minimum temperature of coldest month (69\%), and temperature annual range (8.1\%).

The cranial and postcranial measurements of the specimen fell within the range of the Colombian (Velazco \& Gardner, 2009) and Ecuadorian specimens 


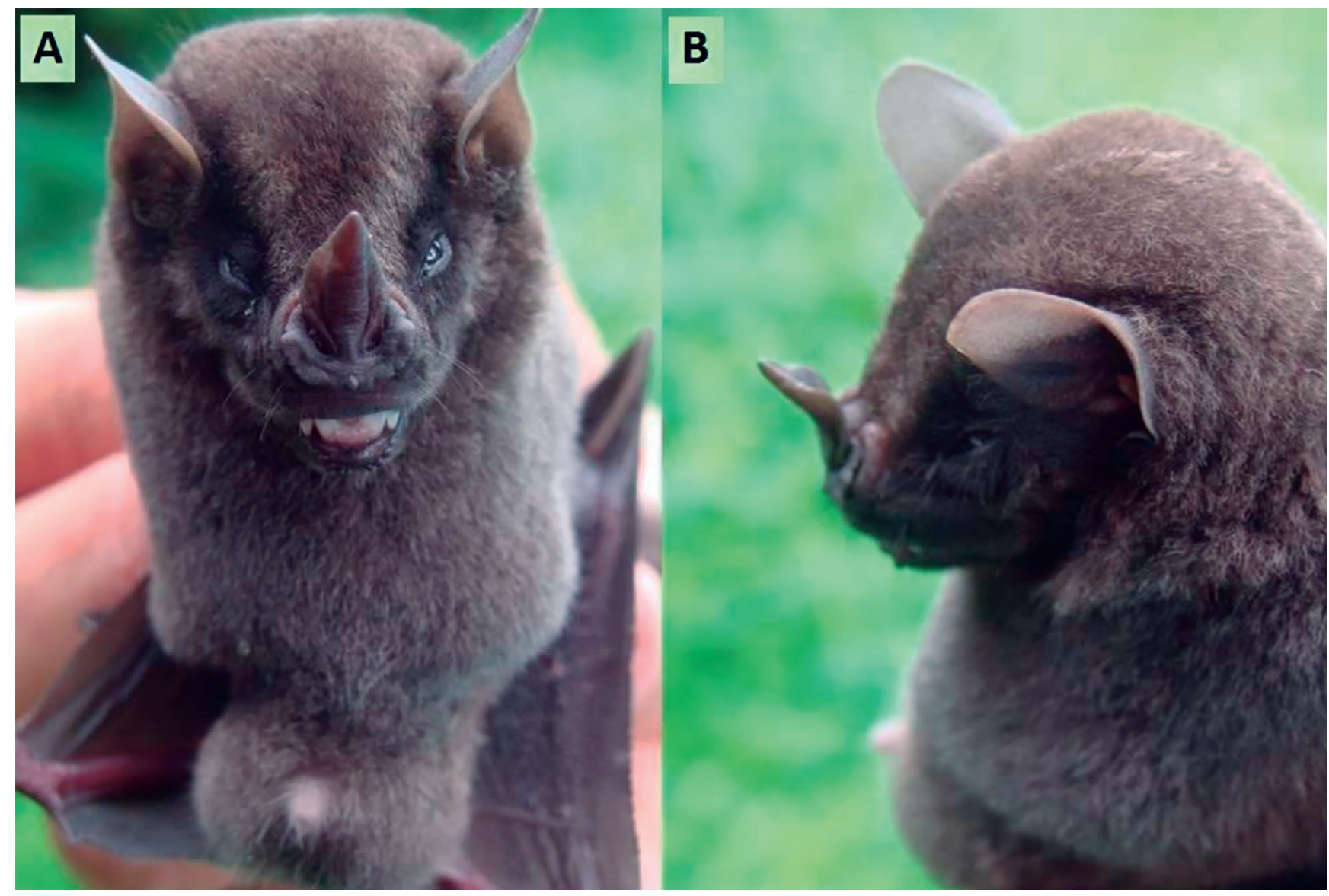

Figure 1. Frontal (A) and lateral (B) views of a live specimen of Platyrrhinus chocoensis collected by WEPR and RAB in San Antonio Farm (voucher number MIZI2012397).

(Table 1). Based on the $P$. chocoensis vouchers deposited in MECN, QCAZ, TTU, and on our record, we propose that the new species distribution extends to Santo Domingo de los Tsáchilas province (Fig. 2). Furthermore, according to Burneo \& Tirira (2014), it may extend to the Los Rios Province and may reach the lowland moist forests of the Los Guayas Province, considering the similar ecological characteristics of these forests.

\section{DISCUSSION}

Vertebrate and invertebrate distribution extension records are not uncommon across the Americas and are mainly based on studies of Natural Reserve Areas (Pereira, 2010; Gregory et al., 2015; Pachelle et al., 2015; Medina et al., 2016; Sikes \& Allen, 2016). This is also the case in Ecuador, where most field studies on Chiroptera were conducted in areas belonging to the National System of Protected Areas (Baker et al., 2009; Loaiza-S, 2010; Moratelli \& Wilson, 2011). This leaves agricultural areas, and agrosystems in general, open to scrutinized fieldwork with potentially interesting findings on bat distribution. In effect, absence of bat distributional data in areas affected by human activities may be mainly due to lack of monitoring effort, considering their floristic and climatic similarities to non-anthropogenically impacted areas. It is thus very likely to expect distribution extension records of bats in such areas, as with the present report. The Ecuadorian Rain Forests belonging to the
Choco-Darien ecoregion were originally settled in the Esmeraldas, Manabí, Santo Domingo de los Tsáchilas, Los Rios, Western Pichincha and Eastern Guayas Provinces (CEPF, 2005), so a record of endemic Chocoan species was to be expected in any locality of these provinces. In fact, Burneo \& Tirira (2014) predicted the potential southern extent in the distribution of $P$. chocoensis before the present report.

Ramirez-Chaves \& Suarez-Castro (2015) report that P. chocoensis occurs in the lowlands of southern Panama and the Pacific region of Colombia, south to northwestern Ecuador. However, according to our observations on specimens deposited in museums made before this report, $P$. chocoensis in Ecuador occurred only in the Esmeraldas province.

Considering the ecological similarities across ecosystems (Drechsler et al., 2007), many mammals demonstrate very wide distribution ranges, such as the recent record of Coendu istichillus (Voss \& da Silva, 2001) at $900 \mathrm{~km}$ away from the known boundaries of its previously recognized distribution area (Gregory et al., 2015). In fact, the scientific literature argues that the majority of range extension records are due to lack of monitoring effort (Rocha et al., 2013; Salas et al., 2013, Novaes et al., 2014). On the other hand, one should also consider that landscape and ecosystem anthropogenic modifications may further contribute to range extension. The present record of $P$. chocoensis was noted in an altered zone occupied by agricultural landscape, and this may indicate that some species are in the process of adapting to en- 


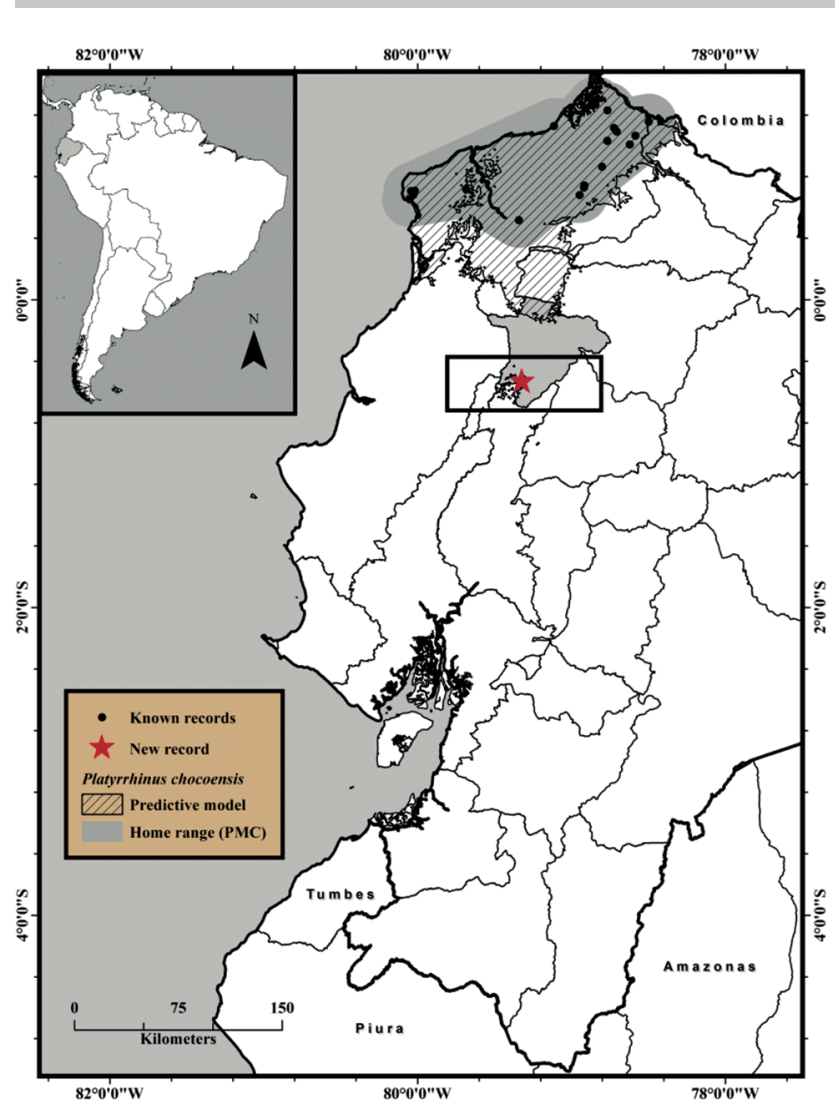

Figure 2. Predictive habitat model using Maxent (AUC value $=0.987$ ), based on 31 specimens with accurate collection sites (black circles) and the new record of Platyrrhinus chocoensis. The shadow under the predictive model corresponds to home range extension before our record. The star represents the new southernmost record reported in this communication.

vironmental changes (Darwin, 1869; Hansen et al., 2001; Schmidt \& Jensen, 2003).

Northwestern Ecuadorian ecosystems have been greatly changed by agriculture (Maestri \& Paterson, 2016). The finding of vulnerable species such as $P$. chocoensis in these areas places a great responsibility on conservationists and environmental scientists and educators. Joint actions are necessary to effectively conserve mammal species in agricultural landscapes. A special concern involves educating local stakeholders on the important ecological role of bats, especially the species directly linked to agricultural production, as landholders and farmworkers believe that bats are harmful, extracting blood from cattle or destroying fruit plantations. This results in an intentional and significant decline in bat populations around farms, rendering their protection and conservation in agrosystems a difficult but crucial task, requiring local policies to undertake appropriate bat conservation programs.

Several farms implement life fences, dispersed tree cover pastures, forest fragments, and riparian forest to promote wildlife conservation on agroecosystems (Vilchez-Mendoza et al., 2014). These ecological production alternatives do not guarantee the survival of the species on farms, however. Many bats are killed by smoke from fires set by landholders who are unaware of the ecological importance of bats for pest control, pollination, and seed dispersal.
Table 1. Comparative cranial and postcranial measurements of $P$. chochoensis from San Antonio farm in Santo Domingo de los Tsáchilas Province (MIZI2012397), from published work by Velazco \& Gardner (2009), and from specimens deposited in mammalian collections in Ecuador [mean \pm SD, range (number of specimens)]. Measurement acronyms are explained in Appendix 2.

\begin{tabular}{|c|c|c|c|}
\hline $\begin{array}{c}\text { Postcranial* and } \\
\text { cranial measurements }\end{array}$ & MIZI2012397 & $\begin{array}{c}\text { Velazco \& Gardner } \\
(2009) \\
\end{array}$ & $\begin{array}{c}\text { Ecuadorian } \\
\text { Museums }\end{array}$ \\
\hline$H B^{*}$ & 73 & - & $\begin{array}{c}72.72 \pm 3.37 \\
67-80(20)\end{array}$ \\
\hline$F^{*}$ & 20.5 & - & $\begin{array}{c}18.84 \pm 1.53 \\
14.28-21.00(20)\end{array}$ \\
\hline$E^{*}$ & 15.51 & - & $\begin{array}{c}13.77 \pm 1.71 \\
11.00-17.00(20)\end{array}$ \\
\hline$F A^{*}$ & 51.46 & $\begin{array}{c}48.8 \pm 1.20 \\
46.9-50.7(19)\end{array}$ & $\begin{array}{c}49.41 \pm 2.93 \\
39.69-53.00(20)\end{array}$ \\
\hline$W^{*}$ & 28 & - & $\begin{array}{c}29.97 \pm 4.71 \\
18.00-35.00(15)\end{array}$ \\
\hline GLS & 28.14 & $\begin{array}{c}27.6 \pm 0.64 \\
26.5-29.0(21)\end{array}$ & $\begin{array}{c}28.45 \pm 0.85 \\
25.35-29.15(18)\end{array}$ \\
\hline $\mathrm{CCL}$ & 24.76 & $\begin{array}{c}24.8 \pm 0.66 \\
23.6-25.9(21) \\
\end{array}$ & $\begin{array}{c}25.07 \pm 0.82 \\
22.24-26.15(18)\end{array}$ \\
\hline ClL & 25.6 & $\begin{array}{c}25.2 \pm 0.67 \\
24.3-26.6(21)\end{array}$ & $\begin{array}{c}25.77 \pm 0.89 \\
22.68-27.35(18)\end{array}$ \\
\hline$B B$ & 11.36 & $\begin{array}{c}11.8 \pm 0.19 \\
11.3-12.2(21)\end{array}$ & $\begin{array}{c}11.86 \pm 0.38 \\
10.67-12.34(18)\end{array}$ \\
\hline$Z B$ & 16.84 & $\begin{array}{c}16.5 \pm 0.43 \\
15.6-17.2(21) \\
\end{array}$ & $\begin{array}{c}16.69 \pm 0.83 \\
13.88-17.56(18)\end{array}$ \\
\hline PB & 6.28 & $\begin{array}{c}6.4 \pm 0.21 \\
6.0-6.8(21)\end{array}$ & $\begin{array}{c}6.51 \pm 0.23 \\
6.03-6.83(18)\end{array}$ \\
\hline$M B$ & 12.51 & $\begin{array}{c}12.6 \pm 0.19 \\
12.2-12.9(21)\end{array}$ & $\begin{array}{c}12.82 \pm 0.45 \\
11.14-13.23(18)\end{array}$ \\
\hline $\mathrm{PL}$ & 14.45 & $\begin{array}{c}14.1 \pm 0.45 \\
13.2-15.0(21)\end{array}$ & $\begin{array}{c}14.46 \pm 0.56 \\
12.51-15.21(18)\end{array}$ \\
\hline MLTRL & 8.45 & - & $\begin{array}{c}8.66 \pm 0.31 \\
7.82-9.26(18)\end{array}$ \\
\hline MTRL & 11.04 & $\begin{array}{c}10.7 \pm 0.32 \\
10.1-11.3(21) \\
\end{array}$ & $\begin{array}{c}10.67 \pm 0.41 \\
9.28-11.20(18) \\
\end{array}$ \\
\hline M1-M1 & 10.61 & $\begin{array}{c}11.0 \pm 0.36 \\
10.2-11.6(21)\end{array}$ & $\begin{array}{c}11.35 \pm 0.38 \\
10.56-12.16(18)\end{array}$ \\
\hline M2-M2 & 11.52 & $\begin{array}{c}11.5 \pm 0.32 \\
10.7-12.1(21) \\
\end{array}$ & $\begin{array}{c}11.72 \pm 0.36 \\
10.72-12.35(18)\end{array}$ \\
\hline MXBR & 6.1 & - & $\begin{array}{c}6.72 \pm 0.23 \\
6.26-7.18(18) \\
\end{array}$ \\
\hline$C-C$ & 7.34 & - & $\begin{array}{c}7.5 \pm 0.42 \\
6.04-7.95(18)\end{array}$ \\
\hline DENL & 19.56 & $\begin{array}{c}19.6 \pm 0.54 \\
18.8-20.5(21) \\
\end{array}$ & $\begin{array}{c}19.95 \pm 0.78 \\
17.22-20.96(18)\end{array}$ \\
\hline MANDL & 11.86 & $\begin{array}{c}11.6 \pm 0.31 \\
11.0-12.1(21)\end{array}$ & $\begin{array}{c}12.36 \pm 0.26 \\
11.78-12.85(17)\end{array}$ \\
\hline $\mathrm{COH}$ & 7.07 & - & $\begin{array}{c}7.05 \pm 0.37 \\
5.91-7.60(18)\end{array}$ \\
\hline
\end{tabular}

\section{CONCLUSIONS}

The distribution of Platyrrhinus chocoensis extends to the province of Santo Domingo de los Tsáchilas, Ecuador. Furthermore, taking into account similarities between ecosystems, the species may also inhabit rain forests or agroecological farms of Los Rios Province up to the western rain forests of Los Guayas Province. Considering its Vulnerable status, developing conservation measures such as environmental education campaigns is crucial to raise awareness of the importance of bats for crops in agricultural areas to guarantee the continuality of this range. 


\section{ACKNOWLEDGEMENTS}

This article is part of WEPR's dissertation submitted to the Universidad de la Habana as partial fulfillment of his doctoral degree. The Vicerrectorado de Investigaciones of the Universidad de las Fuerzas Armadas ESPE (Ecuador) supported field studies. Many thanks go to the following curators and collections staff for providing specimens under their responsibility: Miguel Pinto and Pablo Moreno (MEPN), Jorge Brito (MECN), and Santiago Burneo (QCAZ). Bryan Medina, a volunteer at MIZI, and Jocelyne Yazán of Universidad Central del Ecuador, helped take measurements of skulls deposited in MEPN and MECN. Dionisios Youlatos of Aristotle University of Thessaloniki (Greece) reviewed the preliminary English version and gave us useful technical comments. The final English version was reviewed by Andrea Jones of the Lawrence Berkeley National Lab (USA).The authors declare no conflict of interest during this work.

\section{REFERENCES}

Alberico, M.S. \& Velasco, E. 1991. Description of a new broad-nosed bat from Colombia. Bonner Zoologische Beiträge, 42: 237-239.

Albuja, L. 1999. Murciélagos del Ecuador. 2.ed. Quito-Ecuador, Cicetronic Cía Ltda.

Albuja, L. 2011. Lista de mamíferos actuales del Ecuador. Quito, Ecuador Instituto de Ciencias Biológicas. Escuela Politécnica Nacional. Available at: http://bibdigital.epn.edu.ec/handle/15000/3843. Access in: 04/02/2016.

Albuja, L.; Almendariz, A.; Barriga, S.; Montalvo, L.D.; Cáceres, F. \& Román, J.L. 2012. Fauna de vertebrados del Ecuador. Quito, Ecuador, Instituto de Ciencias Biológicas, Escuela Politécnica Nacional.

Baker, R.J.; Molly, M.; McDonough, M.M.; Swier, V.J.; Larsen, P.A.; Carrera, J.P. \& Ammerman, L.K. 2009. New species of bonneted Bat, genus Eumops (Chiroptera: Molossidae) from the Lowlands of Western Ecuador and Peru. Acta Chiropterologica, 11(1): 1-13.

Balzarini, M.G.; Gonzalez, L.; Tablada, M.; Casanoves, F.; Di Rienzo, J.A. \& Robledo C.W. 2013. InfoStat: manual del usuario. Córdoba-Ar., Editorial Brujas.

Boada, C. 2006. El Chocó biogeográfico. Ecuador terra incognita. № 40. Available at: www.terraecuador.net/revista $40 / 40$ choco.htm. Access in: 11/04/2016.

Botero-Chica, C.A. 2010. El Choco biogeográfico, un tesoro de la naturaleza. Available at: www.ecoportal.net/Temasespeciales/Biodiversidad/ el choco biogeografico un tesoro de la naturaleza. Access in: $11 / 04 / 2016$.

Burneo, S.F. \& Tirira, D.G. 2014. Murciélagos de Ecuador: un análisis de sus patrones de riqueza, distribucion y aspectos de conservación. Therya, 5(1): 197-184.

Burneo, S.F.; Proaño, M.D. \& Tirira, D.G. 2015. Plan de acción para la conservación de los murciélagos del Ecuador. Quito-Ecuador, Programa para la Conservación de los Murciélagos del Ecuador y Ministerio del Ambiente del Ecuador.

CEPF - Critical Ecosystem Partnership Fund. 2005. Ecosystem profile: ChocóManabi conservation corridor Colombia and Ecuador. Crytical Ecosystems Partnership Fund. Available at: www.cepf.net/sites/default/files/final. chocodarienwesternecuador.chocomanabi.briefingbook.pdf. Access in: 26/03/2016.
Cueva-Arroyo, X.A.; Pozo-Rivera, W.E. \& Peck, M.R. 2013. Chiroptera of Junin, with the first record of Vampyrum spectrum (Linnaeus, 1758) for the province of Imbabura - Ecuador. Cobiofrag IASA Boletín Técnico 11, Serie Zoológica, 8-9: 1-15.

Darwin, C. 1869. On the origins of species by means of natural selections. London, Jhon Murray Albemarle Streeth.

Drechsler, M.; Grimm, V.; Mysiak, J. \& Watzold, F. 2007. Differences and similarities between ecological and economic models for biodiversity conservation. Ecological Economics, 62(2): 232-241.

Gardner, A.L. 2007. Genus Platyrrhinus Saussure, 1860. In: Gardner AL (Ed.). Mammals of South America: Marsupials, Xenarthrans, Shrews, and Bats. Chicago, The University of Chicago Press. v. 1, p. 329-342.

Gregory, T.; Lunde, D.; Zamora-Meza, H.T. \& Carrasco-Rueda, F. 2015. Records of Coendou ichillus (Rodentia, Erethizontidae) from the Lower Urubamba Region of Peru. ZooKeys, 509: 109-121.

Hansen, A.J.; Neilson, R.P.; Dale, V.H.; Flather, C.H.; Iverson, L.R.; Currie D.J.; Shafer, S.; Cook, R. \& Bartlein, P.J. 2001. Global change in forests: responses of species, communities, and biomes. BioScience, 51(9): 765-769.

Hijmans, R.J.; Cameron, S.E.; Parra, J.L.; Jones, P.G. \& Jarvis, A. 2005. Very high resolution interpolated climate surfaces for global land areas. International Journal of Climatology, 25: 1965-1978.

Huttel, C.; Zebrowski, C. \& Gondard, P. 1999. Paisajes agrarios del Ecuador, geografía básica del Ecuador. Quito, Institut de Recherche por le Développement, Instituto Panamericano de Geografía e Historia, Institut Français d'Études Andines, Instituto Geográfico Militar, Pontificia Universidad Católica del Ecuador. v. 5

Jarrín-V, P. \& Kunz, T.H. 2001. A new species of Sturnira (Chiroptera: Phyllostomidae) from the Choco forest of Ecuador. Zootaxa, 2755: 1-35.

Jones, J.K. \& Carter, D.C. 1976. Annotated checklist, with keys to subfamilies and genera. In: Baber, R.J.; Jones Jr., J.K. \& Carter, D.C. (Eds.). Biology of bats of the new world family Phyllostomidae. Lubbock TX, Museum Texas Tech University. pt. 1, p. 7-38.

Kalko, E.K.V.; Estrada-Villegas, S.; Schmidt, M.; Wegmann, M. \& Meyer, C.F.J. 2008. Flying high-assessing the use of the aerosphere by bats. Integrative and Comparative Biology, 48(1):60-73.

Lim, B.K. 1993. Cladistic reappraisal of Neotropical stenodermatine bat phylogeny. Cladistics, 9(2): 145-165.

Loaiza-S, C.R. 2010. Primer registro de Artibeus fraterculus (Chiroptera: Phyllostomidae) en una zona de matorral húmedo montano en la provincia de Loja, Ecuador. Boletín Técnico 9, Serie Zoológica, 6: 78-84. (Publicacion Cientifica del Departamento de Ciencias de la Vida Ecuador)

MAE - Ministerio de Ambiente del Ecuador. 2015. Sistema nacional de áreas protegidas del Ecuador. Available at: http://areasprotegidas.ambiente. gob.ec. Access in: 18/04/2016.

Maestri, R. \& Patterson, B.D. 2016. Patterns of species richness and turnover for the South American rodent fauna. PLOS ONE, 11(3): e0151895.

Medina, C.E.; Pino, K.; Pari, A.; Llerena, G.; Zeballos, H. \&López E. 2016. Mammalian diversity in the savanna from Peru, with three new addictions from country. Papéis Avulsos de Zoologia, 56(2): 9-26.

Mittermeier, R.A.; Mittermeier, C.G. \& Myers, N. 1999. Hotspots: Earth's biologically richest and most endangered terrestrial ecoregions. México DF, Conservation International, CEMEX, S.A. de C.V., Agrupación Sierra Madre.

Moratelli, R. \& Wilson, D.E. 2011. A new species of Myotis Kaup, 1829 (Chiroptera, Vespertiolinidae) from Ecuador. Mammalian Biology, 76: 608-614.

Myers, N.; Mittermeier, R.A.; Mittermeier, C.G.; da Fonseca, G.A.B. \& Kent, J. 2000. Biodiversity hotspots for conservation priorities. Nature, 403 : 853-858. 
Novaes, R.L.M.; Souza, R.F.; Felix, S.; Jacob, G.; Sauwen, C. \& Avilla, L.S. 2014. Occurrence of Phyllostomus elongatus (Geoffroy St.-Hilaire, 1810) (Chiroptera, Phyllostomidae) in the Cerrado of Tocantins and a compilation of its Brazilian distribution. Check List, 10(1): 213-216.

Pachelle, P.P.G.; Anker, A. \& Tavares, M. 2015. New and additional records of the sponge shrimp genus Typton Costa, 1844 (Decapoda: Palaemonidae) from the Brazilian coast. Papéis Avulsos de Zoologia, 55(22): 317-322.

Paredes, K. 2010. El video participativo como herramienta de aprendizaje y reflexión sobre el cambio social. Gestion Ambiental, 1(2): 13-16.

Pereira, L.A. 2010. First record of a ballophilid centipede from French Guiana with a description of Ityphilus betschi sp. nov. (Myriapoda: Chilopoda: Geophilomorpha). Papéis Avulsos de Zoologia, 50(42): 643-665.

Phillips, S.J.; Anderson, R.P. \& Schapire, R.E. 2006. Maximum entropy modeling of species geographic distributions. Ecological Modeling, 190: 231-259.

Pozo-Rivera, W.E. 2013. Mamíferos de hábitats fragmentados de la provincia Santo Domingo de los Tsáchilas. Sangolquí-Ecuador, Edi-ESPE.

Pozo-Rivera, W.E. 2017. Relaciones de la diversidad arbórea y la estructura del paisaje agrícola tropical ecuatoriano con la biodiversidad de murciélagos filostómidos. Ph.D. Dissertation. Universidad de La Habana, La Habana.

Pozo-Rivera, W.E. \& Eras, A. 2012. Bats present in riparian forests in farms in Santo Domingo de los Tsáchilas, Ecuador. In: Tirira D.G. \& Burneo, S.F. (Eds.). Investigación y conservación sobre los murciélagos en el Ecuador. Quito, Pontificia Universidad Católica del Ecuador, Fundación Mamíferos y Cnservación y Asociación Ecuatoriana de Mastozoología. p. 61-68.

Pozo-Rivera, W.E.; Recalde, R.S.; Cárdenas-Tello, C.D.; Morejón-García, M. \& Berovides-Álvarez, V. 2015. Diversidad quiropterológica de dos tipos de cultivos, Noroccidente Ecuatoriano. CIBA, Boletín Técnico 12, Serie Zoológica, 10-11: 95-103.

Ramirez-Chaves, H. \& Suárez-Castro, A. 2015. Platyrrhinus chocoensis. The IUCN Red List of Threatened Species 2015: e.T17568A21987035. Available at: file:///C:/Users/Dione/Downloads/10.2305_IUCN.UK.20154.RLTS.T17568A21987035.en.pdf. Access in: 11/03/2016.

Rocha, P.A.; Mikalauskas, J.S.; Bocchiglieri, A.; Feijó, J.A. \& Ferrari, S.F. 2013. An update on the distribution of the Brazilian funnel-eared bat, Natalus acrourus (Gervais, 1856) (Mammalia, Chiroptera), with new records from the Brazilian Northeastern. Check List, 9(3): 675-679.

Salas, J.A.; Viteri-H, F.; Zambrano-M, M.; Benavides-H, V. \& Carvajal-M, R. 2013. Distribution extension of proboscis bat Rhynchonycteris naso (Wied-Neuwied, 1820) (Chiroptera: Emballonuridae): New record for southwestern Ecuador. Check List, 9(5): 1054-1056.

Schmidt, N.M. \& Jensen, P.M. 2003. Changes in mammalian body length over 175 years: adaptations to a fragmented landscape? Conservation Ecology, $7(2): 6$.

Sierra, R.; Campos, F. \& Chamberlin, J. 2002. Assessing biodiversity conservation priorities: ecosystems risk and representativeness in continental Ecuador. Landscape and Urban Planning, 59: 95-110.
Sikes, D.S. \& Allen, R.T. 2016. First Alaskan records and a significant northern range extension for two species of Diplura (Diplura, Campodeidae). ZooKeys, 563: 147-157.

Sikes, R.S.; Gannon, W.L. \& The animal care and use Committee of the American Society of Mammalogists. 2011. Guidelines of the American Society of Mammalogists for the use of wild mammals in research. Journal of Mammalogy, 92(1): 235-253.

Simmons, N.B. 2005. Order Chiroptera. In: Wilson, D.E. \& Reeder, D.M. (Eds.). Mammals species of the world: a taxonomic and geographic reference. 3.ed. Baltimore, The Johns Hopkins University Press. p. 314-529.

Tello, J.G. \& Velazco, P.M. 2003. First description of a tent used by Platyrrhinus helleri (Chiroptera: Phyllostomidae). Acta Chiropterologica, 5(2): 269-276.

Tirira, D.G. 2007. Mamíferos del Ecuador: guía de campo. Quito, Ediciones Murciélago Blanco. (Publicación Especial 6).

Tirira, D.G. 2008. Mamíferos de los bosques húmedos del noroccidente de Ecuador. Quito, Ediciones Murciélago Blanco y Proyecto PRIMENET. (Publicación Especial 7).

Tirira, D.G. 2016. Mamiferos del Ecuador: lista actuaizada de especies / Mammals of Ecuador: updated species check list. Version 2016. Ecuador, Asociación Mamíferos y Conservación and Asociación Ecuatoriana Mastozoología. 28p. Available at: www.mamiferosdelecuador.com/ images/pdf/Lista22016.pdf. Access in: 15/08/2017.

Velazco, P.M. 2005. Morphological phylogeny of the bat genus Platyrrhinus Saussure, 1860 (Chiroptera: Phyllostomidae) with the description of four new species. Fieldiana Zoology, n.S., 105: 1-54.

Velazco, P.M. \& Gardner, A.L. 2009. A new species of Platyrrhinus (Chiroptera: Phyllostomidae) from western Colombia and Ecuador, with emended diagnoses of $P$. aquilus, $P$. dorsalis, and $P$. umbratus. Proceedings of the Biological Society of Washington, 122(3): 249-281.

Velazco, P.M. \& Lim, B.K. 2014. A new species of broad-nosed bat Platyrrhinus Saussure, 1860 (Chiroptera: Phyllostomidae) from the Guianan Shield. Zootaxa, 3796(1): 175-193.

Velazco, P.M., Gardner, A.L. \& Patterson, B.D. 2010. Systematics of the Platyrrhinus helleri species complex (Chiroptera: Phyllostomidae), with descriptions of two new species. Zoological Journal of the Linnean Society, 159: 785-812.

Vilchez-Mendoza, S.; Harvey, C.A.; Saenz, J.C.; Casanoves, F.; Carvajal, J.P.; Gonzalez-Villalobos, J.; Hernandez, B.; Medina, A.; Montero, J.; SanchezMerlo, D. \& Sinclair, F.L. 2014. Consistency in bird use of tree cover across tropical agricultural landscapes. Ecological Applications, 24(1): 158-168.

Voss, R.S. \& da Silva, M.N.F. 2001. Revisionary notes on the Neotropical porcupines (Rodentia: Erethizontidae) 2: a review of the Coendou vestitus group with descriptions of two new species from Amazonia. American Museum Novitates, 3351: 1-36.

Zuppinger-Dingley, D.; Flynn, D.F.B.; Brandl, H. \& Schmid, B. 2015. Selection in monoculture vs. mixture alters plant metabolic fingerprints. Journal of Plant Ecology, 8(5): 549-557. 


\section{APPENDIX 1}

\section{Examined specimens deposited in Ecuadorian museum}

Museum acronyms are found in the methodology section, localities are present as follow:

PROVINCE (Number of specimens)

County:

Parish,

Locality, Latitude, Longitude: MUSEUM NUMBER ( $F=$ female, $M=$ male, $U=$ Unknown sex).

CARCHI (5)

Tulcán:

Tobar Donoso,

Vía Lita Bosque Maduro, 0109'27.0”N , 78²9'50.3"W: MECN2884 (F), MECN2872 (M), MECN3263 (M), MECN2913 (F), MECN without voucher number (U).

ESMERALDAS (43)

\section{Eloy Alfaro:}

La tola,

Molina stream, $2 \mathrm{~km}$ south Mataje, $01^{\circ} 07^{\prime} 45.6^{\prime \prime} \mathrm{N}, 79^{\circ} 06^{\prime} 46.4^{\prime \prime} \mathrm{W}:$ MEPN004320 (U), MEPN004323 (M).

Luis Vargas Torres,

2 km south Playa de Oro; 0051'56.7"N, 7848'04.6"W: MEPN3177 (F), MEPN3178(F), MEPN1923 (F), MEPN001924 (U), MEPN6678 (M).

Telembi,

3 km south San Miguel town; 0043'00"N, 78 ${ }^{\circ} 55^{\prime} 08^{\prime \prime}$ W: MEPN3013 (F), MEPN3072 (F), MEPN3075 (F).

Poblado San Miguel; 0043'47.8"N, 78 55'08.9"W: MEPN003263 (F).

Salto del Rio Bravo; 0040'53.4"N, 7856'46.1"W: MEPN9133 (F), MEPN9134 (M), MEPN2110 (M), MEPN2121 (F).

\section{Muisne:}

\section{San Francisco,}

Chipa stream; 00²'26.0"N, 8002' 33.7"W: MECN3073 (M).

El Aguacate stream; $00^{\circ} 39^{\prime} 12.5^{\prime \prime} \mathrm{N}, 80^{\circ} 03^{\prime} 06.8^{\prime \prime} \mathrm{W}$ : MECN2081 (M).

Inés stream; 0040'54.7"N, 8001'39.6"W: MECN3064 (M).

Partidero stream, Poza Honda; 0042'32.8”N, 8001'01.7"W: MECN3109 (F).

\section{Quinindé:}

Malimpia,

Sade Town, $8 \mathrm{~km}$ east of Sade river; 00³1'04.0"N, 79²0'28.9”W: MEPN3361 (U), MEPN003362 (F), MEPN3398 (5 specimens: $3 \mathrm{~F}, 1 \mathrm{M}, 1 \mathrm{U}$ ).

\section{San Lorenzo:}

\section{San Lorenzo,}

Crnl. Carlos Torres, Taquiama stream, right side Rio Tiaone, $00^{\circ} 43^{\prime} \mathrm{N}, 79^{\circ} 41^{\prime} \mathrm{W}$ : MEPN3459 (M).

Choco, San Lorenzo, 01¹6'10.6"N, 7850'38.1"W: QCAZ9208 (F).

Estación Experimental "La chiquita", 12 km south San Lorenzo, 01¹3'55.2"N, 7845'57.7"W: MEPN002120 (F), TTU85426 (F), TTU???? (F).

\section{Santa Rita,}

San Francisco de Bogotá, 14 km east San Lorenzo, 0105'36.8”N $78^{\circ} 42^{\prime} 21.5^{\prime \prime} \mathrm{W}:$ TTU???? (U).

San José farm $24 \mathrm{~km}$ east San Lorenzo, $01^{\circ} 00^{\prime} 36^{\prime \prime} \mathrm{N}, 78^{\circ} 37^{\prime} 20^{\prime \prime} \mathrm{W}:$ TTU???? (M).

Recinto Durango, Bloque Quijano; 010.'00.2"N, 7843'24.0”W: MECN2211 (F), MECN2239 (M), MECN2245 (M), MECN2238 (F), MECN2249 (F).

\section{Tululbi,}

Centro Comunal Mataje, North Awá Reserve, 0104'00.0"N, 78³4'59.9"W: MEPN2050 (F), MEPN3673 (F), MEPN3700 (F).

Urbina,

Urbina, $01^{\circ} 02^{\prime} \mathrm{N}, 78^{\circ} 46^{\prime} \mathrm{W}:$ MEPN1931 (M), MEPN1932 (M).

SANTO DOMINGO DE LOS TSÁCHILAS (1)

\section{Santo Domingo:}

Luz de América,

Hacienda San Antonio, km 42, Road Santo-Domingo-Quevedo, 00³1'32.0”S, 79¹9'21.0"W: MIZI2012397 (M). 
APPENDIX 2

\section{Meaning of acronym used in Table 1, for explain how to measure them see Velazco (2005) and Velazco \& Gardner (2009)}

$\mathrm{HB}=$ Head body length; $F=$ foot length; $E=$ ear length; $F A=$ forearm length; $W=$ weight expressed in $\mathrm{mm}$; $G L S=$ greatest length of skull; $C C L=$ condylocanine length; $C I L=$ condyloincisive length; $B B=$ braincase breadth; $Z B=$ zygomatic breadth; $\mathrm{PB}=$ postorbital breadth; $\mathrm{MB}=$ mastoid breadth; $\mathrm{PL}=$ palatal length; $\mathrm{MLTRL}=$ molariform toothrow length; $\mathrm{MTRL}=$ maxillary toothrow length; $\mathrm{M} 1-\mathrm{M} 1$ = width across first upper molars; $\mathrm{M} 2-\mathrm{M} 2$ = width across second upper molars; $\mathrm{MXBR}=$ breadth across maxillae; $\mathrm{C}-\mathrm{C}=$ palatal width at canines; $\mathrm{DENL}=$ length of dentary; $\mathrm{MANDL}=$ length of mandibular toothrow; $\mathrm{COH}=$ coronoid height. 